\title{
Synthesis, spectroscopic characterization and catalytic oxidation properties of ONO/ONS donor Schiff base ruthenium(III) complexes containing $\mathrm{PPh}_{3} / \mathrm{AsPh}_{3}$
}

\author{
S PRIYAREGA ${ }^{\mathrm{a}}$, M MUTHU TAMIZH $^{\mathrm{b}}, \mathrm{R}_{\mathrm{K}} \mathrm{KARVEMBU}^{\mathrm{b}}, \mathrm{R}^{\mathrm{PRABHAKARAN}}{ }^{\mathrm{a}}$ and \\ K NATARAJAN ${ }^{\mathrm{a}, *}$ \\ ${ }^{a}$ School of Chemistry, Bharathiar University, Coimbatore 641 046, India \\ ${ }^{b}$ Department of Chemistry, National Institute of Technology, Tiruchirappalli 620 015, India \\ e-mail: k_natraj6@yahoo.com
}

MS received 6 July 2010; revised 3 January 2011; accepted 4 March 2011

\begin{abstract}
Six different ruthenium(III) complexes of Schiff bases derived from 2-hydroxy-1-naphthaldehyde and $o$-aminophenol/o-aminothiophenol have been synthesized. The compounds with the general formula $\left[\mathrm{RuX}\left(\mathrm{EPh}_{3}\right)_{2}(\mathrm{~L})\right](\mathrm{X}=\mathrm{Cl}$ or $\mathrm{Br} ; \mathrm{E}=\mathrm{P}$ or As; $\mathrm{L}=$ bifunctional tridentate $\mathrm{ONO} / \mathrm{ONS}$ donor Schiff base ligand $)$ were characterized by infrared, electronic, electron paramagnetic resonance spectroscopy and elemental analyses. Spectroscopic investigation reveals coordination of Schiff base ligand through ONO/ONS donor atoms and octahedral geometry around ruthenium metal. Redox property of complexes has been examined by using cyclic voltammetry. The catalytic oxidation property of ruthenium(III) complexes were also investigated.
\end{abstract}

Keywords. Ruthenium(III); Schiff base ligand; triphenylphosphine; triphenylarsine; catalytic oxidation.

\section{Introduction}

Complexes of transition and non-transition metals with Schiff bases have been investigated extensively for many years because of their importance in many applications. ${ }^{1-5}$ These complexes have important contribution in the development of catalysis, magnetism, molecular architectures and materials chemistry.

Oxidation of alcohols to carbonyl compounds is one of the most pivotal functional group transformations in organic synthesis. Three important natural enzymes used for oxidation reactions are cytochrome P-450, peroxidases and catalases. All these enzymes have iron(III) porphyrin as the central unit. Hence, several investigations have been made on the reactions of synthetic metalloporphyrins to understand the mechanism of action of porphyrin containing enzymes. ${ }^{6}$ Though metalloporphyrins catalyse oxidation reactions, the catalytic yield is not satisfactory to have any commercial viability. Moreover, it is not easy to synthesize metalloporphyrins and this led scientists to look for other ligands to make novel complexes to be employed as catalysts in oxidation reactions. ${ }^{7}$ Hence, studies on synthesis

*For correspondence and catalytic activity of metal complexes derived from Schiff base ligands have gained greater momentum. ${ }^{8}$ In addition, triphenylphosphine/triphenylarsine transition metal complexes are well known for its catalytic applications in various organic transformations. ${ }^{9,10}$ The synthesis, characterization and catalytic applications of several hexa coordinated ruthenium(III) complexes containing Schiff base and triphenylphosphine have been reported by us earlier. ${ }^{11}$ This paper deals with the synthesis, spectroscopic characterization and catalytic oxidation properties of ruthenium(III) Schiff base complexes obtained from the reactions of $\left[\mathrm{RuCl}_{3}\left(\mathrm{PPh}_{3}\right)_{3}\right]$, $\left[\mathrm{RuCl}_{3}\left(\mathrm{AsPh}_{3}\right)_{3}\right]$ or $\left[\mathrm{RuBr}_{3}\left(\mathrm{AsPh}_{3}\right)_{3}\right]$ with Schiff bases derived from 2-hydroxy-1-naphthaldehyde and $o$-aminophenol $/ o$-aminothiophenol.

\section{Experimental}

All the solvents used were dried and purified by standard methods. IR spectra were recorded as $\mathrm{KBr}$ pellets with a Nicolet FT-IR spectrophotometer in the 4000$400 \mathrm{~cm}^{-1}$ range. Electronic spectra of the complexes were recorded in acetonitrile solution using a Shimadzu spectrophotometer in the $800-200 \mathrm{~nm}$ range. Magnetic susceptibility measurements were made with auto magnetic susceptibility balance. Microanalyses were 
carried out with a VarioEL AMX-400 elemental analyzer. EPR spectra of powdered samples were recorded with a Jeol TEL-100 instrument at X-band frequencies at room temperature. Cyclic voltammetric studies were carried out with a BAS CV-27 model electrochemical analyzer in acetonitrile using a glassycarbon working electrode and the potentials were referenced to an $\mathrm{Ag} / \mathrm{AgCl}$ electrode. Melting points were recorded with a Boetius micro heating table and were uncorrected. The starting complexes $\left[\mathrm{RuCl}_{3}\left(\mathrm{PPh}_{3}\right)_{3}\right],{ }^{12}$ $\left[\mathrm{RuCl}_{3}\left(\mathrm{AsPh}_{3}\right)_{3}\right],{ }^{13}\left[\mathrm{RuBr}_{3}\left(\mathrm{AsPh}_{3}\right)_{3}\right]^{14}$ and the ligands ${ }^{15,16}$ were prepared by reported literature methods.

\subsection{Preparation of ruthenium(III) complexes}

To a solution of $\left[\mathrm{RuX}_{3}\left(\mathrm{EPh}_{3}\right)_{3}\right](\mathrm{X}=\mathrm{Cl}$ or $\mathrm{Br} ; \mathrm{E}=\mathrm{P}$ or As) $(0.1 \mathrm{mmol})$ in toluene $(15 \mathrm{~mL})$, appropriate Schiff base ligand $(0.1 \mathrm{mmol})$ in $\mathrm{CH}_{2} \mathrm{Cl}_{2}(10 \mathrm{~mL})$ was added (molar ratio of ruthenium complex: Schiff base was $1: 1)$. The solution was heated under reflux for $6 \mathrm{~h}$. Then it was concentrated to a small volume $(3 \mathrm{~mL})$ and the new complex was separated from it by the addition of a small quantity $(6 \mathrm{~mL})$ of $n$-hexane. The product was filtered, washed with $n$-hexane and crystallized from $\mathrm{CH}_{2} \mathrm{Cl}_{2} / n$-hexane mixture and dried in vacuo. Yield: 61-69\%.

\subsection{Procedure for catalytic oxidation}

To a solution of alcohol $(1 \mathrm{mmol})$ in dichloromethane $(20 \mathrm{~mL}), N$-methylmorpholine- $N$-oxide $(0.35 \mathrm{~g} ; 3 \mathrm{mmol})$ and the ruthenium complex $(0.01 \mathrm{mmol})$ were added. The solution was refluxed for $5 \mathrm{~h}$. The mixture was evaporated to dryness and extracted with petroleum ether $\left(60-80^{\circ} \mathrm{C}\right)$. The extract was filtered and evaporated to give the corresponding carbonyl compound which were then quantified as their 2,4dinitrophenylhydrazones.

\section{Results and discussion}

\subsection{Synthesis}

The tridentate Schiff bases $\left(\mathrm{H}_{2} \mathrm{~L}\right)$ react with the ruthenium(III) complexes of the general formula $\left[\mathrm{RuX}_{3}\left(\mathrm{EPh}_{3}\right)_{3}\right](\mathrm{X}=\mathrm{Cl}$ or $\mathrm{Br} ; \mathrm{E}=\mathrm{P}$ or $\mathrm{As})$ in $1: 1$ molar ratio in $\mathrm{CH}_{2} \mathrm{Cl}_{2}$-toluene mixture to yield complexes of the type $\left[\mathrm{RuX}\left(\mathrm{EPh}_{3}\right)_{2}(\mathrm{~L})\right]$ (scheme 1). The analytical data obtained for the new complexes are in good agreement with the proposed molecular formulae (table 1). It is found that the Schiff bases behave as binegative tridentate ligands.

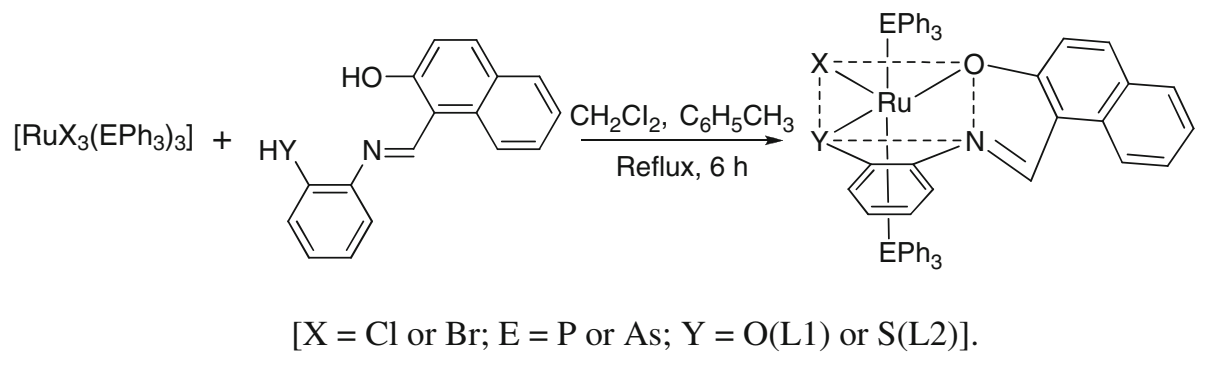

Scheme 1. Formation of ruthenium(III) complexes.

Table 1. Analytical data for the ruthenium(III) complexes.

\begin{tabular}{llccccc}
\hline \multirow{2}{*}{ Complex } & \multirow{2}{*}{ Colour } & \multirow{2}{*}{ m.p. $\left({ }^{\circ} \mathrm{C}\right)$} & \multicolumn{4}{c}{ Elemental analysis, Found (Calc.) (\%) } \\
\cline { 5 - 7 } & & & $\mathrm{C}$ & $\mathrm{H}$ & $\mathrm{N}$ & $\mathrm{S}$ \\
\hline$\left[\mathrm{RuCl}\left(\mathrm{PPh}_{3}\right)_{2}(\mathrm{~L} 1)\right](\mathbf{1})$ & green & 178 & $68.64(69.01)$ & $4.13(4.48)$ & $1.30(1.52)$ & - \\
{$\left[\mathrm{RuCl}\left(\mathrm{PPh}_{3}\right)_{2}(\mathrm{~L} 2)\right](\mathbf{2})$} & brown & 224 & $67.29(67.83)$ & $4.17(4.40)$ & $1.44(1.50)$ & $3.03(3.42)$ \\
{$\left[\mathrm{RuCl}\left(\mathrm{AsPh}_{3}\right)_{2}(\mathrm{~L} 1)\right](\mathbf{3})$} & brick red & 138 & $62.83(63.00)$ & $3.93(4.06)$ & $1.18(1.39)$ & - \\
{$\left[\mathrm{RuCl}\left(\mathrm{AsPh}_{3}\right)_{2}(\mathrm{~L} 2)\right](\mathbf{4})$} & brown & 130 & $61.67(62.01)$ & $3.74(4.03)$ & $1.22(1.36)$ & $2.70(3.12)$ \\
{$\left[\operatorname{RuBr}\left(\mathrm{AsPh}_{3}\right)_{2}(\mathrm{~L} 1)\right](\mathbf{5})$} & dark green & 144 & $60.02(60.34)$ & $3.67(3.92)$ & $1.12(1.33)$ & - \\
{$\left[\operatorname{RuBr}\left(\mathrm{AsPh}_{3}\right)_{2}(\mathrm{~L} 2)\right](\mathbf{6})$} & dark brown & 128 & $59.08(59.44)$ & $3.51(3.86)$ & $1.16(1.31)$ & $2.70(2.99)$ \\
\hline
\end{tabular}




\subsection{Electronic spectra}

The ground state of ruthenium(III) is ${ }^{2} T_{2 g}$ and the first excited doublet levels in the order of increasing energy are ${ }^{2} A_{2 \mathrm{~g}}$ and ${ }^{2} A_{1 \mathrm{~g}}$ which arises from the $t_{2 \mathrm{~g}}^{4} e_{\mathrm{g}}^{1}$ configuration. ${ }^{17}$ In most of the ruthenium(III) complexes, the UV-Vis spectra show only charge transfer bands. ${ }^{18}$ Since in a $\mathrm{d}^{5}$ system, and especially in ruthenium(III) which has relatively high oxidizing properties, the charge transfer bands of the type $\mathrm{L}_{\pi \mathrm{y}} \rightarrow t_{2 \mathrm{~g}}$ are prominent in the low energy region which obscure the weaker bands due to $d-d$ transition. It is therefore becomes difficult to assign conclusively the bands of ruthenium(III) complexes which appear in the visible region. The electronic spectra of all the complexes in acetonitrile showed four to five bands in the region $500-210 \mathrm{~nm}$ (table 2, figure 1). A band around $440-500 \mathrm{~nm}\left(\varepsilon=3840-11877 \mathrm{~mol}^{-1} \mathrm{~cm}^{-1} \mathrm{dm}^{3}\right)$ has been assigned as due to $\mathrm{d}-\mathrm{d}$ transition. The extinction coefficients of the bands in the region $210-390 \mathrm{~nm}$ $\left(\varepsilon=7983-52371 \mathrm{~mol}^{-1} \mathrm{~cm}^{-1} \mathrm{dm}^{3}\right.$ ) have been found to be higher than those generally expected for $d-d$ transitions. Hence, these bands have been assigned to charge transfer transitions. Similar observations have been made for other ruthenium(III) octahedral complexes. ${ }^{19}$

Table 2. IR and electronic spectral data ${ }^{a}$ for the ruthenium(III) Schiff base complexes.

\begin{tabular}{|c|c|c|c|c|c|}
\hline Compound & $v(\mathrm{C}=\mathrm{N})$ & $v(\mathrm{C}-\mathrm{O})$ & $v(\mathrm{C}-\mathrm{S})$ & Bands due to $\mathrm{PPh}_{3} / \mathrm{AsPh}_{3}$ & $\lambda_{\max }(\varepsilon)$ \\
\hline $\mathrm{H}_{2} \mathrm{~L} 1$ & 1631 & 1320 & - & - & - \\
\hline $\mathrm{H}_{2} \mathrm{~L} 2$ & 1622 & 1323 & 1244 & - & - \\
\hline 1 & 1582 & 1385 & - & $1432,1075,685$ & $\begin{array}{l}\text { 213(48931), 221(48540), } \\
\text { 265(20426), 320(9703), } \\
442(9720)\end{array}$ \\
\hline 2 & 1604 & 1390 & 1262 & $1432,1092,695$ & $\begin{array}{l}227(51051), 269(32880), \\
390(11371), 477(8948)\end{array}$ \\
\hline 3 & 1626 & 1350 & - & $1434,1079,689$ & $\begin{array}{l}223(52371), 317(11714), \\
386(9825), 442(11443), \\
461(10937)\end{array}$ \\
\hline 4 & 1582 & 1396 & 1262 & $1433,1077,690$ & $\begin{array}{l}217(47462), 262(18629), \\
290(14700), 497(10937)\end{array}$ \\
\hline 5 & 1599 & 1391 & - & $1434,1093,694$ & $\begin{array}{l}218(50222), 228(52280), \\
320(11537), 441(12368), \\
462(11877)\end{array}$ \\
\hline 6 & 1581 & 1391 & 1261 & $1433,1076,687$ & $\begin{array}{l}225(51114), 265(20877), \\
322(7983), 465(3840)\end{array}$ \\
\hline
\end{tabular}

${ }^{\text {a }} v$ in $\mathrm{cm}^{-1} ; \lambda$ in $\mathrm{nm}, \varepsilon$ in $\mathrm{mol}^{-1} \mathrm{~cm}^{-1} \mathrm{dm}^{3}$
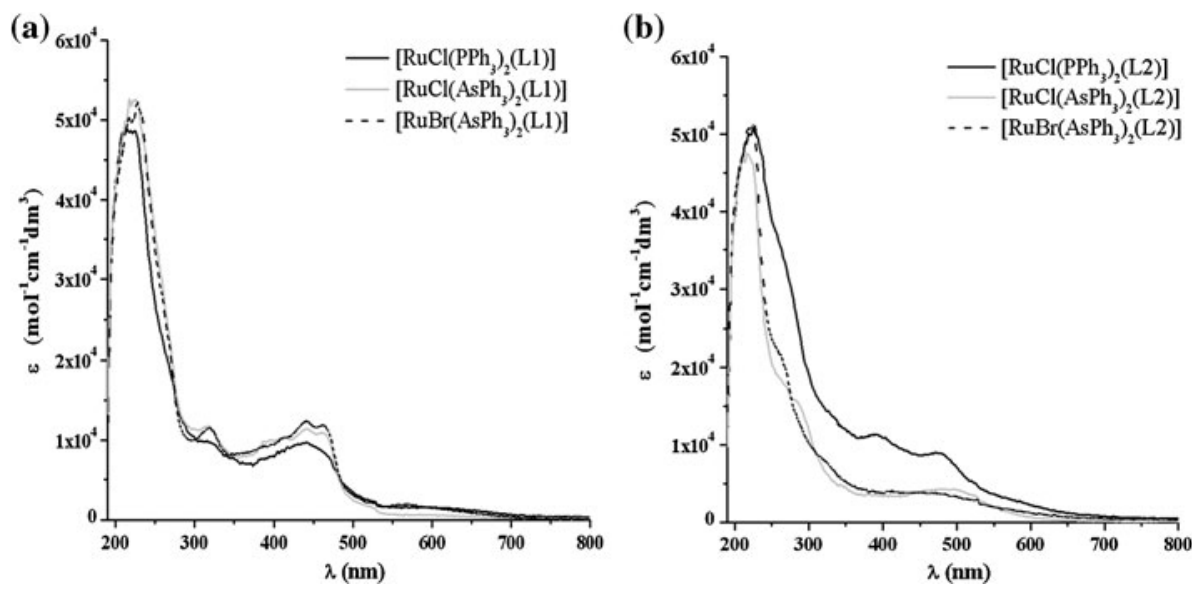

Figure 1. Electronic spectra of ruthenium(III) complexes (a, b). 


\subsection{IR spectra}

The results of IR measurements are given in table 2 . The IR spectra of all the free Schiff bases show the characteristic $-\mathrm{CH}=\mathrm{N},-\mathrm{OH}$ and $-\mathrm{SH}$ frequencies around 1630,3500 and $2600 \mathrm{~cm}^{-1}$ respectively. A strong band observed at $1320-1323 \mathrm{~cm}^{-1}$ in the ligands has been assigned to phenolic $\mathrm{C}-\mathrm{O}$ stretching. On complexation, the band due to $-\mathrm{C}=\mathrm{N}$ stretching underwent a negative shift $\left(1581-1626 \mathrm{~cm}^{-1}\right)$, suggesting the involvement of azomethine group in coordination. ${ }^{20}$ The phenolic $\mathrm{C}-\mathrm{O}$ stretching band has been shifted to $1325-1396 \mathrm{~cm}^{-1}$ region in the complexes, which shows that the other coordination site is phenolic oxygen atom. ${ }^{21}$ The binding mode of the Schiff base ligands to the ruthenium ion in these complexes is further confirmed by the disappearance of broad band at $3500 \mathrm{~cm}^{-1}$ attributed to $-\mathrm{OH}$ in the complexes. The band corresponding to $\mathrm{S}-\mathrm{H}$ also disappears in the complexes containing $\mathrm{H}_{2} \mathrm{~L} 2$ ligand. The band due to $\mathrm{C}-\mathrm{S}$ of $\mathrm{H}_{2} \mathrm{~L} 2\left(1244 \mathrm{~cm}^{-1}\right)$ is shifted into the range 1261$1262 \mathrm{~cm}^{-1}$ in these complexes, providing an additional evidence for the participation of the $-\mathrm{SH}$ group in the complex formation. The bands due to $\mathrm{PPh}_{3} / \mathrm{AsPh}_{3}$ are also observed in the expected region. ${ }^{22}$

Table 3. EPR spectral data for ruthenium(III) complexes.

\begin{tabular}{lcccc}
\hline Complex & $\mathrm{g}_{\mathrm{x}}$ & $\mathrm{g}_{\mathrm{y}}$ & $\mathrm{g}_{\mathrm{z}}$ & $<\mathrm{g}>*$ \\
\hline $\mathbf{1}$ & 1.68 & 1.68 & 1.85 & 1.74 \\
$\mathbf{2}$ & - & 1.87 & - & - \\
$\mathbf{3}$ & 1.62 & 1.62 & 1.88 & 1.71 \\
$\mathbf{4}$ & - & 1.86 & - & - \\
\hline$<\mathrm{g}>^{*}=\left[1 / 3 \mathrm{~g}_{\mathrm{x}}^{2}+1 / 3 \mathrm{~g}_{\mathrm{y}}^{2}+1 / 3 \mathrm{~g}_{\mathrm{z}}^{2}\right]^{1 / 2}$ & &
\end{tabular}

\subsection{Magnetic moments}

The magnetic moments of all the complexes have been measured at room temperature using an auto magnetic susceptibility balance. The $\mu_{\text {eff }}$ value for these complexes is in the range of 1.7 to $1.8 \mathrm{~B} . \mathrm{M}$. This shows that these complexes are paramagnetic corresponding to one unpaired electron, which supports the trivalent state of ruthenium.

\subsection{EPR spectra}

The new ruthenium(III) complexes are paramagnetic and hence EPR spectra were recorded for powdered samples in solid state at X-band frequencies. The $\mathrm{g}$ values listed in table 3 show that $\left[\mathrm{RuCl}\left(\mathrm{PPh}_{3}\right)_{2}(\mathrm{~L} 1)\right]$ and $\left[\mathrm{RuCl}\left(\mathrm{AsPh}_{3}\right)_{2}(\mathrm{~L} 1)\right]$ exhibit spectra with a $\mathrm{g}_{\perp}$ at $1.62-1.68$ and $\mathrm{g}_{\|}$at $1.85-1.88$ (figure $2 \mathrm{a}$ ). The presence of two $g$ values is an indication of an octahedral field with tetragonal distortion $\left(g_{x}=g_{y} \neq g_{z}\right)$ and also points out an axial symmetry for the complexes and hence trans positions are assigned to $\mathrm{PPh}_{3} / \mathrm{AsPh}_{3}$ groups. ${ }^{23}$ The $\left[\mathrm{RuCl}\left(\mathrm{PPh}_{3}\right)_{2}(\mathrm{~L} 2)\right]$ and $\left[\mathrm{RuCl}\left(\mathrm{AsPh}_{3}\right)_{2}(\mathrm{~L} 2)\right]$ complexes show a well-defined single isotropic line with $\mathrm{g}$ values in the range of 1.86-1.87 (figure 2b). Such isotropic lines are usually the results of either intramolecular spin exchange, which may broaden the lines, or occupancy of the unpaired electron in a degenerate orbital. Similar EPR behaviour was observed for Schiff base ruthenium(III) complexes. ${ }^{11,24}$

\subsection{Cyclic voltammetry}

The electrochemical behaviour of all the synthesized complexes was studied by cyclic voltammetry in the range +2.0 to $-2.0 \mathrm{~V}$ in acetonitrile using glassy
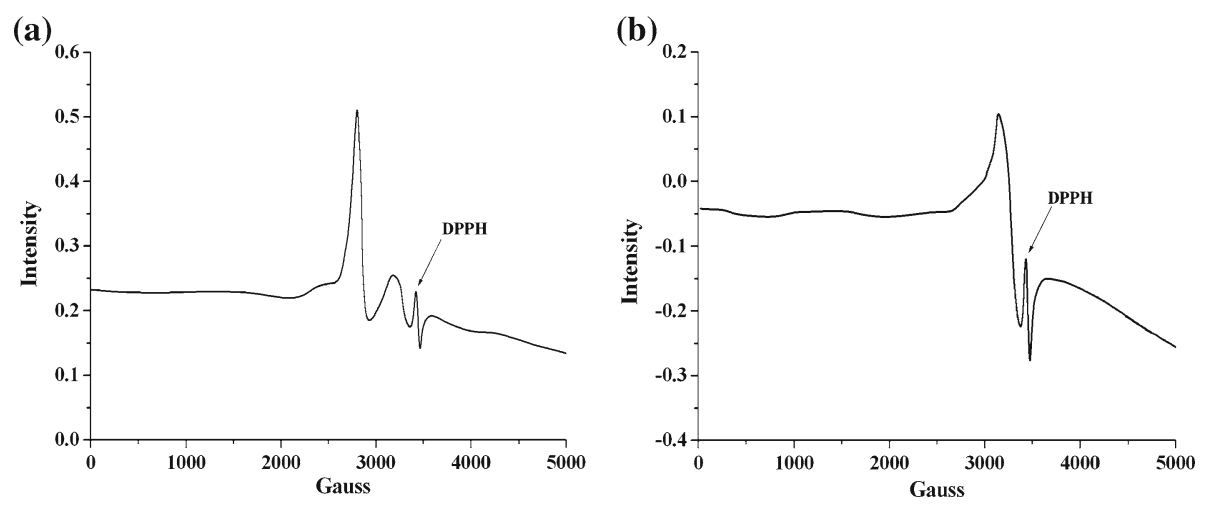

Figure 2. EPR spectra of $\mathbf{3}$ and $\mathbf{2}(\mathbf{a}, \mathbf{b})$. 
carbon as working electrode, $\mathrm{Ag} / \mathrm{AgCl}$ as reference electrode and $\left[\mathrm{NBu}_{4}\right] \mathrm{ClO}_{4}(0.1 \mathrm{M})$ as supporting electrolyte. The solution was degassed with a continuous flow of nitrogen gas before scanning. All the complexes are electroactive only with respect to metal centre. The complexes $\left(10^{-3} \mathrm{M}\right)$ gave only quasi reversible cyclic voltammetric response due to $\mathrm{Ru}^{\mathrm{III}}-\mathrm{Ru}^{\mathrm{II}}$ couple in the range of $\mathrm{E}_{1 / 2}=-0.87$ to $-0.82 \mathrm{~V}$, with peak to peak separation $\left(\Delta E_{p}\right)$ of $210-240 \mathrm{mV}$ (table 4$)$. This is attributed to slow electron transfer and adsorption of the complexes onto the electrode surface. ${ }^{25}$ The $\mathrm{E}_{1 / 2}$ and $\Delta \mathrm{E}_{\mathrm{p}}$ values are in good agreement with those recently reported for other similar ruthenium(III) Schiff base complexes. ${ }^{19,23}$ A representative voltammogram has been depicted in figure 3 . The $\mathrm{E}_{1 / 2}$ (reduction) values of

Table 4. Cyclic voltammetric data ${ }^{\mathrm{a}}$ for ruthenium(III) Schiff base complexes.

\begin{tabular}{ll}
\hline Complex & $\mathrm{E}_{1 / 2}^{\mathrm{b}}\left(\Delta \mathrm{E}_{\mathrm{p}}\right)^{\mathrm{c}}$ \\
\hline $\mathbf{1}$ & $-0.835(210)$ \\
$\mathbf{2}$ & $-0.820(220)$ \\
$\mathbf{3}$ & $-0.860(240)$ \\
$\mathbf{4}$ & $-0.870(220)$ \\
$\mathbf{5}$ & $-0.865(210)$ \\
$\mathbf{6}$ & $-0.860(220)$ \\
\hline a & Supporting electrolyte:[NBu$] \mathrm{NlO}_{4}$
\end{tabular}

a Supporting electrolyte: $\left[\mathrm{NBu}_{4}\right] \mathrm{ClO}_{4}$ $(0.1 \mathrm{M})$; scan rate, $100 \mathrm{mV} \mathrm{s}^{-1}$; reference electrode, $\mathrm{Ag}-\mathrm{AgCl}$.

b $\mathrm{E}_{1 / 2}$ in Volts; $\mathrm{E}_{1 / 2}=0.5\left(\mathrm{E}_{\mathrm{pa}}+\right.$ $E_{p c}$ ), where $E_{p a}$ and $E_{p c}$ are the anodic and cathodic peak potentials in Volts, respectively.

${ }^{c} \Delta \mathrm{E}_{\mathrm{p}}$ in $\mathrm{mV} ; \Delta \mathrm{E}_{\mathrm{p}}=\mathrm{E}_{\mathrm{pa}}-\mathrm{E}_{\mathrm{pc}}$

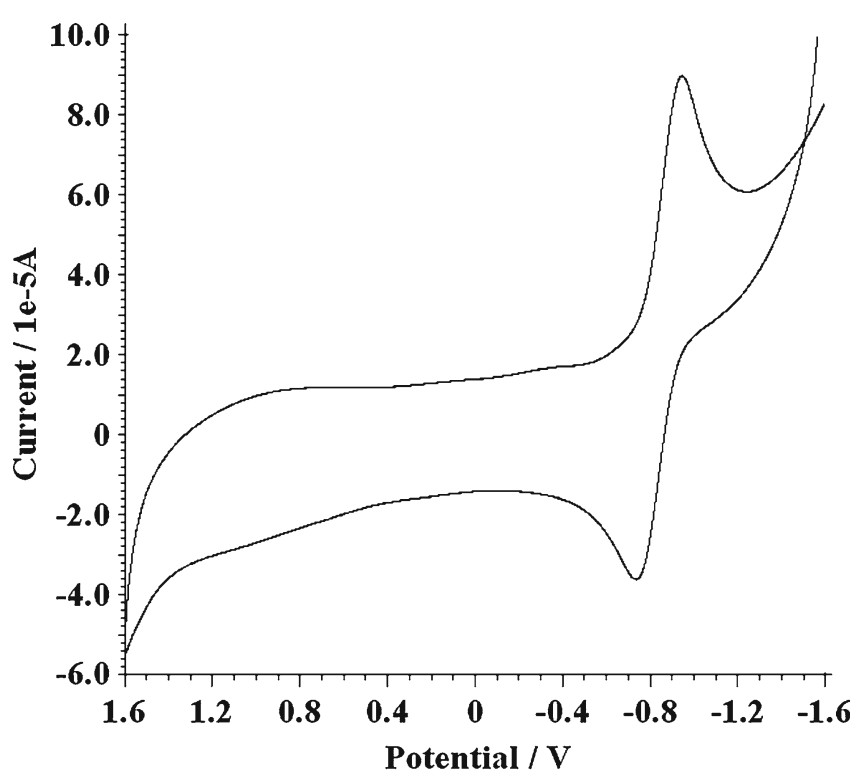

Figure 3. Cyclic voltammogram of $\mathbf{1}$. the complexes containing one phenyl ring in the aldehyde part of the Schiff base ligands range from -0.52 to $-0.63 \mathrm{~V} .{ }^{11}$ When these values are compared with that of new complexes, it has been observed that the addition of one phenyl ring in the ligand causes positive shift in the $E_{1 / 2}$ (reduction) values. This can be explained by the fact that the additional phenyl ring, by its electron withdrawing nature decreases the electron density around the metal centre. ${ }^{26}$ There is no variation in the redox potential of the complexes due to the replacement of triphenylphosphine by triphenylarsine. ${ }^{19}$

Our attempts to grow crystals suitable for X-ray structural determination were unsuccessful. Hence, trans positions of $\mathrm{PPh}_{3} / \mathrm{AsPh}_{3}$ and the equatorial position of remaining ligands have been assigned on the basis of single crystal X-ray structure of other similar octahedral ruthenium(III) complexes. ${ }^{27,28}$ The alternate structure in which ' $\mathrm{X}$ ' is trans to ' $\mathrm{O}$ ' is not ruled out.

\section{Catalytic activities}

The oxidation of benzyl alcohol, 1-phenylethanol and cyclohexanol, using ruthenium complexes as catalysts in the presence of $\mathrm{N}$-methylmorpholine- $\mathrm{N}$-oxide (NMO) as co oxidant, was carried out in $\mathrm{CH}_{2} \mathrm{Cl}_{2}$. The reaction is also carried out with $\mathrm{H}_{2} \mathrm{O}_{2}, \mathrm{O}_{2}$, air or

Table 5. Catalytic activity data ${ }^{\mathrm{a}}$ of ruthenium(III) complexes.

\begin{tabular}{lllc}
\hline Complex & \multicolumn{1}{c}{ Substrate } & \multicolumn{1}{c}{ Product } & Yield $(\%)^{\mathrm{b}}$ \\
\hline $\mathbf{1}$ & Benzyl alcohol & Benzaldehyde & 64 \\
& 1-Phenylethanol & Acetophenone & 72 \\
$\mathbf{2}$ & Cyclohexanol & Cyclohexanone & 61 \\
& Benzyl alcohol & Benzaldehyde & 68 \\
& 1-Phenylethanol & Acetophenone & 70 \\
$\mathbf{3}$ & Cyclohexanol & Cyclohexanone & 57 \\
& Benzyl alcohol & Benzaldehyde & 60 \\
& 1-Phenylethanol & Acetophenone & 68 \\
& Cyclohexanol & Cyclohexanone & 54 \\
& Benzyl alcohol & Benzaldehyde & 61 \\
& 1-Phenylethanol & Acetophenone & 70 \\
& Cyclohexanol & Cyclohexanone & 57 \\
& Benzyl alcohol & Benzaldehyde & 57 \\
& 1-Phenylethanol & Acetophenone & 69 \\
$\mathbf{6}$ & Cyclohexanol & Cyclohexanone & 51 \\
& Benzyl alcohol & Benzaldehyde & 57 \\
& 1-Phenylethanol & Acetophenone & 65 \\
& Cyclohexanol & Cyclohexanone & 49 \\
\hline
\end{tabular}

\footnotetext{
${ }^{a}$ Reaction time, $5 \mathrm{~h}$.

b Yields based on substrate.
} 
$t$ - $\mathrm{BuOOH}$ as oxidant; but conversion is not satisfactory. Use of $\mathrm{H}_{5} \mathrm{IO}_{6}$ as oxidant alters the nature of catalyst. Hence, NMO is used as oxidant in catalytic reactions. Benzaldehyde and acetophenone were formed from benzyl alcohol and 1-phenylethanol respectively. Cyclohexanol was converted into cyclohexanone after refluxing for about $5 \mathrm{~h}$. The carbonyl compounds were then quantified as its 2,4-dinitrophenylhydrazone derivatives (table 5). There was no detectable oxidation of alcohol in the presence of NMO alone. The starting complexes, $\left[\mathrm{RuX}_{3}\left(\mathrm{EPh}_{3}\right)_{3}\right](\mathrm{X}=\mathrm{Cl}$ or $\mathrm{Br}$; $\mathrm{E}=\mathrm{P}$ or As) do not show significant catalytic activity (yield $=10-15 \%$ ) compared to new Schiff base Ru(III) complexes. All the synthesized complexes were found to catalyse the oxidation of alcohols to carbonyl compounds. But the yield and the turnover vary with the different catalysts used. The low product yield obtained for oxidation of cyclohexanol compared to benzyl alcohol and 1-phenylethanol is due to the fact that $\alpha-\mathrm{CH}$ unit of cyclohexanol is less acidic than benzyl alcohol and 1-phenylethanol. ${ }^{29}$ The yields obtained from the reactions catalysed by $\mathrm{Ru}-\mathrm{PPh}_{3}$ complexes are slightly higher compared to that of $\mathrm{Ru}-\mathrm{AsPh}_{3}$ complexes because $\mathrm{Ru}-\mathrm{P}$ bond is more labile than $\mathrm{Ru}-\mathrm{As}$ bond. ${ }^{30}$ To study the effect of additional phenyl ring in the aldehyde part of Schiff base ligands, catalytic activity of new $\mathrm{Ru}(\mathrm{III})$ complexes was compared with already reported $\mathrm{Ru}(\mathrm{III})$ complexes containing Schiff base ligand that posses only one phenyl ring in the aldehyde part. ${ }^{11}$ It has been observed that no significant change in catalytic oxidation of benzyl alcohol but catalytic activity is significantly enhanced for the oxidation of cyclohexanol. This may be attributed to the increase in electron withdrawing nature of the ligand due to the increased resonance by the additional phenyl ring. ${ }^{31}$ In general, the new ruthenium(III) complexes exhibit lower catalytic activity compared to other similar ruthenium(III) complexes of the type $\left[\mathrm{RuX}_{2}\left(\mathrm{EPh}_{3}\right)_{2}(\mathrm{~L})\right](\mathrm{X}=\mathrm{Cl}$ or $\mathrm{Br} ; \mathrm{E}=\mathrm{P}$ or As; $\mathrm{L}=N$ [di(alkyl/aryl)carbamothioyl]benzamide derivatives). ${ }^{32}$ This may be due to the fact that the present ligand system is not suitable for stabilizing higher oxidation states. This is inferred from electrochemical studies as cyclic voltammogram did not show $\mathrm{Ru}^{\mathrm{IV}}-\mathrm{Ru}^{\mathrm{III}}$ couple. Hence the relationship between catalytic activity and $\mathrm{E}_{1 / 2}$ values could not be made.

\section{Conclusion}

Mononuclear $\mathrm{Ru}(\mathrm{III})$ complexes of the type $\left[\mathrm{RuX}\left(\mathrm{EPh}_{3}\right)_{2}(\mathrm{~L})\right](\mathrm{X}=\mathrm{Cl}$ or $\mathrm{Br} ; \mathrm{E}=\mathrm{P}$ or As; $\mathrm{L}=$ bifunctional tridentate Schiff base ligand) were prepared and characterized by UV-Vis, IR and EPR spectroscopy. Electrochemical behaviour of the complexes has been examined. The complexes act as catalysts for the oxidation of alcohols to carbonyl compounds in presence of NMO.

\section{Acknowledgement}

$\mathrm{K} \mathrm{N}$ thanks Council of Scientific and Industrial Research (CSIR) for the award of Emeritus Scientist position.

\section{References}

1. Holm R H and O'Connor M J 1971 Prog. Inorg. Chem. 14241

2. Costamagna J, Vargas J, Lattorre R, Alvarado A and Mena G 1992 Coord. Chem. Rev. 11967

3. Garnovskii A D, Nivorozhkin A L and Minkin V I 1993 Coord. Chem. Rev. 1261

4. Guerriero P 1995 Coord. Chem. Rev. 13917

5. Luo H, Franwick P E and Green M A 1998 Inorg. Chem. 371127

6. Stevens E D 1981 J. Am. Chem. Soc. 1035087

7. Bhowon M G 2000 Indian J. Chem. 39A 1207

8. Srinivasan K, Perrier S and Kochi J K 1986 J. Mol. Cat. 36297

9. Naresh Kumar K, Ramesh R and Liu Y 2007 J. Mol. Cat. A: Chem. 265218

10. Rosales M, Alvarado B, Arrieta F, De La Cruz C, González A, Molina K, Soto O and Salazar Y 2008 Polyhedron 27530

11. Priyarega S, Prabhakaran R, Aranganayagam K R, Karvembu R and Natarajan K 2007 Appl. Organometal. Chem. 21788

12. Chatt J, Leigh G, Mingos D M P and Paske R J 1968 J. Chem. Soc. A 2636

13. Poddar R K, Khullar I P and Agarwala U 1974 Inorg. Nucl. Chem. Lett. 10221

14. Natarajan K, Poddar R K and Agarwala U 1977 J. Inorg. Nucl. Chem. 39431

15. Mazzi U, Refosco F, Tisato F, Bandoli G and Nicolini M 1986 J. Chem. Soc. Dalton Trans. 1623

16. Tisato F, Refosco F, Mazzi U, Bandolin U and Nicolini M 1987 J. Chem. Soc. Dalton Trans. 1693

17. Ballhausen C J 1962 Ligand field theory (New York: Mc Graw Hill)

18. Lever A B P 1989 Inorganic electronic spectroscopy (New York: Elsevier)

19. Prabhakaran R, Geetha A, Thilagavathi M, Karvembu R, Krishnan V, Bertagnolli H and Natarajan K 2004 J. Inorg. Biochem. 982131

20. Soliman A A and Mohamed G G 2004 Thermochim. Acta $\mathbf{4 2 1} 151$ 
21. Ramesh R and Maheshwaran S 2003 J. Inorg. Biochem. 96457

22. Karvembu R and Natarajan K 2002 Polyhedron 21219

23. Karvembu R, Jayabalakrishnan C, Dharmaraj N, Renukadevi S V and Natarajan K 2002 Transition Met. Chem. 27631

24. Manoharan P T, Mehrothra P K, Khan M M T and Andal R K 1973 Inorg. Chem. 122753

25. Wallace A W, Murphy Jr W R and Peterson J D 1989 Inorg. Chim. Acta 16647

26. Hashimoto T, Hara S, Shiraishi Y, Natarajan K and Shimizu K 2003 Chem. Lett. 32874
27. Prabhakaran R, Huang R, Karvembu R, Jayabalakrishnan C and Natarajan K 2007 Inorg. Chim. Acta 360691

28. Chitrapriya N, Mahalingam V, Zeller M, Jayabalan R, Swaminathan K and Natarajan K 2008 Polyhedron 27 939

29. Chatterjee D, Mitra A and Mukherjee S 2001 J. Mol. Cat. A: Chem. 165295

30. Mahalingam V, Karvembu R, Chinnusamy V and Natarajan K 2006 Spectrochim. Acta Part A 64886

31. Bhattacharya P K 1990 J. Chem. Sci. 102247

32. Gunasekaran N and Karvembu R 2010 Inorg. Chem. Commun. 13952 